\title{
Hyperproinsulinaemia in patients with myotonic dystrophy
}

\author{
A.J.Krentz ${ }^{1}$, P.M.Clark ${ }^{2}$,L.Cox ${ }^{2}$, A.C.Williams ${ }^{3}$ and M.Nattrass ${ }^{1}$ \\ ${ }^{1}$ Diabetic Clinic, The General Hospital, ${ }^{2}$ Department of Clinical Neurology, Queen Elizabeth Hospital, Birmingham; \\ ${ }^{3}$ Department of Clinical Biochemistry, Addenbrooke's Hospital, Cambridge, UK
}

Summary. Hyperinsulinaemia is a reported feature of the inherited multisystem disorder myotonic dystrophy. This phenomenon has been attributed to a compensatory beta cell response to tissue insulin resistance. In this study, circulating concentrations of insulin, proinsulin, and split proinsulin molecules were determined after an overnight fast in ten patients with myotonic dystrophy using two-site monoclonal antibody-based immunoradiometric assays. Results were compared with ten healthy control subjects matched for age, gender, and body mass index. Oral glucose tolerance $(75 \mathrm{~g})$, as defined by World Health Organization criteria, was normal in all subjects. Fasting plasma immunoreactive insulin concentration, as determined using a conventional radioimmunoassay, was almost three times higher $(p<0.005)$ in the myotonic dystrophy patients than the healthy control subjects. By contrast, fasting concentrations (mean \pm SEM) of C-peptide $(0.75 \pm 0.09$ vs $0.52 \pm 0.03 \mathrm{nmol} / 1, p=0.07)$ and immunoradiometrically-determined insulin ( $60 \pm 12$ vs
$38 \pm 4 \mathrm{pmol} / \mathrm{l}, p=0.09)$ were not significantly different between the groups. Fasting concentrations of proinsulin $(10.3 \pm 2.9 \mathrm{vs} 1.6 \pm 0.3 \mathrm{pmol} / \mathrm{l}, p<0.01)$, and $32-33$ split proinsulin $(7.8 \pm 2.5$ vs $2.9 \pm 0.4 \mathrm{pmol} / \mathrm{l}, p<0.05)$ were significantly elevated in the patients with myotonic dystrophy. Accordingly, the mean fasting proinsulin:insulin ratio, expressed as a percentage, was significantly increased in the myotonic patients $(20 \pm 5$ vs $4 \pm 1 \%, p<0.01)$. The overall C-peptide response to the oral glucose challenge was significantly greater in the myotonic patients compared with the healthy control subjects $(p<0.001)$. These results provide corroborative evidence of increased beta-cell secretion in myotonic dystrophy. In addition, myotonic dystrophy is characterised by elevated plasma concentrations of proinsulin-like molecules which may cross-react in insulin radioimmunoassays.

Key words: Myotonic dystrophy, proinsulin, insulin resistance.
Insulin resistance is a characteristic metabolic feature of the multisystem disorder myotonic dystrophy $[1,2]$. While oral glucose tolerance is usually normal or only mildly impaired, markedly elevated plasma immunoreactive insulin concentrations, as determined by radioimmunoassay, are a well-documented feature of the disorder [1]. As in other insulin-resistant states, hyperinsulinaemia in myotonic dystrophy has been attributed to a compensatory beta-cell response to insulin resistance in target tissues $[2,3]$. No intrinsic abnormalities of the insulin molecule have been described and the ratio of circulating proinsulin to insulin, as determined by chromatographic separation followed by radioimmunoassay, is reported to be normal [4].

Recent studies in other insulin-resistant disorders including impaired glucose tolerance [5] and Type 2 (noninsulin-dependent) diabetes mellitus [6] have indicated elevated plasma concentrations of beta-cell conversion intermediates with lower biological potencies than insulin.In this study, fasting concentrations of insulin and proinsulinlike were determined in a group of patients with myotonic dystrophy using two-site immunoradiometric assays.

\section{Patients and methods}

\section{Patients}

Ten fully ambulant patients with unequivocal features of myotonic dystrophy were studied. Eight kindreds were studied; two of the patients were brothers while two others were uncle and nephew, respectively. One patient had a family history of diabetes in a first degree relative. Ten healthy volunteers served as control subjects. The two groups (myotonic dystrophy vs control subjects) were well matched for age ( $36 \pm 9 \mathrm{vs} 36 \pm 13$ years, $p>0.1$ ), gender (male: female, $7: 3$ for each group), and body mass index ( $25 \pm 3$ vs $\left.24 \pm 3 \mathrm{~kg} / \mathrm{m}^{2}, p>0.1\right)$. No subjects had evidence of active hepatic or renal disease as judged by clinical and biochemical criteria, although serum aspartate transaminase was elevated in several of the patients with myotonic dystrophy. Serum creatine kinase was also elevated in these individuals suggest- 

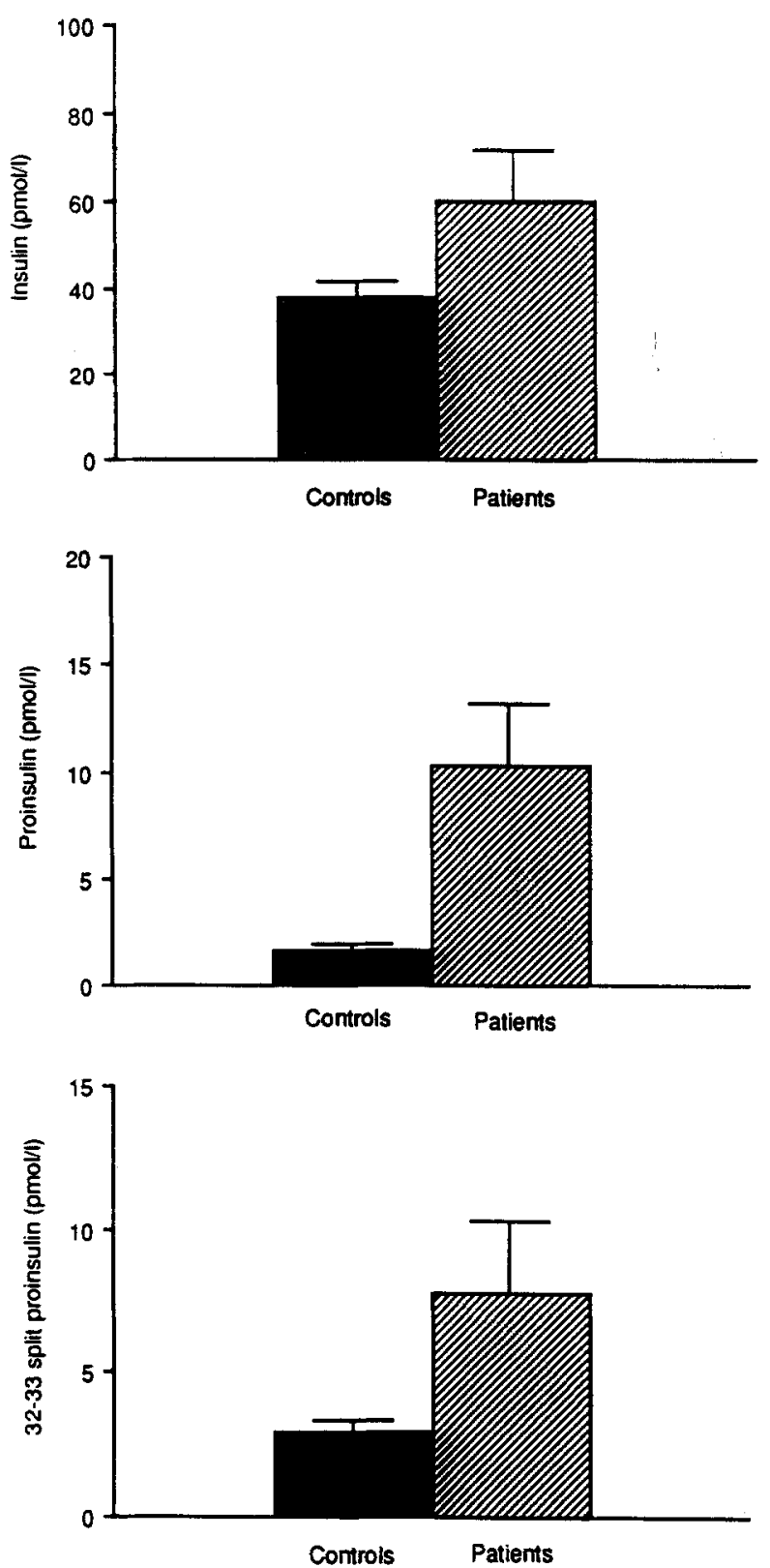

Fig.1. Fasting concentrations (mean and SEM) of insulin (top), proinsulin (middle), and 32-33 split proinsulin (bottom) in patients with myotonic dystrophy $(n=10)$ and healthy control subjects $(n=10)$ as determined by two-site immunoradiometric assays. There was no significant difference between the groups in plasma insulin concentrations $(p=0.09)$. Fasting plasma proinsulin $(p<0.01)$, and 32-33 split proinsulin $(p<0.05)$ concentrations were significantly elevated in the patients with myotonic dystrophy

ing skeletal muscle was the site of origin of the transaminase. No subject was receiving medication known to interfere with endogenous insulin release. Informed written consent for the study was obtained from all subjects, which was approved by the Ethical Committee of the Central Birmingham Health Authority.

\section{Protocol}

Following a $10-\mathrm{h}$ overnight fast, an antecubital vein was cannulated in each subject and kept patent by flushing with $1-2 \mathrm{ml}$ saline $(150 \mathrm{mmol} / \mathrm{l})$. After discarding the first $2 \mathrm{ml}$, free-flowing blood was drawn and placed in tubes containing lithium heparin (LIP; Shipley, West Yorkshire, UK). The blood was centrifuged at $4^{\circ} \mathrm{C}$ and plasma separated and stored at $-20^{\circ} \mathrm{C}$ pending assay for beta-cell products. Glucose tolerance was assessed using a 75 -g oral glucose load under standardised conditions with measurement of immunoreactive insulin and C-peptide at $0,15,30,60,90,120,180,240$, and $300 \mathrm{~min}$.

Assays

Plasma immunoreactive insulin concentration was determined using a double-antibody radioimmunoassay with a sensitivity of $12 \mathrm{pmol} / \mathrm{l}$ (Guildhay, University of Surrey, UK). Cross-reactivity was $100 \%$ for porcine insulin, human insulin and proinsulin, 29\% for 32-33 split proinsulin, and 50\% for 65-66 split proinsulin. Plasma C-peptide concentrations were measured by a double antibody radioimmunoassay (Novo Industries, Bagsvaerd, Denmark) with a cross-reactivity of $80 \%$ with proinsulin.

Fasting plasma concentrations of insulin, proinsulin, and split proinsulin products were measured using two-site monoclonal antibody-based immunoradiometric assays with between assay coefficients of variation of $15 \%$ or less and detection limits ranging between 0.8 to $2.5 \mathrm{pmol} / 1$ [7]. Cross-reactivity of the proinsulin assay was $66 \%$ with $65-66$ split proinsulin, but zero with insulin and 32-33 split proinsulin. Cross-reactivity of the 32-33 split proinsulin assay was $84 \%$ with proinsulin, and $60 \%$ with $65-66$ split proinsulin. Cross-reactivity of the insulin assay was $5.0 \%, 5.3 \%$, and $62 \%$ with 32-33 split proinsulin, intact proinsulin, and 65-66 split proinsulin, respectively [7]. Whole blood glucose concentrations at 0 and 120 min were determined using a hexokinase/glucose 6-phosphate dehydrogenase method [1].

\section{Statistical analysis}

Clinical characteristics and fasting metabolite and hormone concentrations were compared using unpaired $t$-tests after logarithmic transformation of data where appropriate. Correlations were examined using the least squares method. Differences in overall immunoreactive insulin and C-peptide concentrations between the groups during the glucose tolerance tests were analysed by repeated measures analysis of variance. Results are presented in the text as the mean and standard error of the mean (SEM).

\section{Results}

Fasting glucose concentration was normal [8] in all subjects with mean values of $4.8 \pm 0.2$ vs $4.7 \pm 0.1 \mathrm{mmol} / 1(p>0.1)$ for the myotonic dystrophy patients and healthy control subjects, respectively. Oral glucose tolerance, as defined by World Health Organization criteria [8] was normal in all of the myotonic patients and healthy control subjects.

Fasting plasma immunoreactive insulin concentration, as determined by double antibody radioimmunoassay, was significantly elevated in the myotonic patients, being nearly three times higher than that for the healthy control subjects ( $45.0 \pm 9.6 \mathrm{vs} 16.2 \pm 2.4 \mathrm{pmol} / \mathrm{l}, p<0.005$ ). By contrast, fasting plasma insulin concentration, as determined by the immunoradiometric assay (Fig.1), was approximately $50 \%$ higher in the myotonic patients, a difference which did not reach statistical significance $(p=0.09)$. Consistent with the latter observation, the difference in fasting C-peptide levels between the groups did not reach conventional statistical significance $(0.75 \pm 0.09$ vs $0.52 \pm 0.03 \mathrm{nmol} / \mathrm{l}, p=0.07)$. A significant correlation between plasma C-peptide and immunoradiometrically- 
determined insulin concentrations was observed for both the myotonic patients $(r=0.88, p<0.01)$ and the healthy control subjects $(r=0.71, p<0.05)$.

The fasting concentration of proinsulin (Fig. 1) was significantly elevated in the patients with myotonic dystrophy $(10.3 \pm 2.9 \mathrm{vs} 1.6 \pm 0.3 \mathrm{pmol} / 1, p<0.01)$. Accordingly, the circulating proinsulin : insulin ratio, calculated from the individual data and expressed as a percentage, was significantly increased in these patients $(20 \pm 5$ vs $4 \pm 1 \%$, $p<0.01$ ). Plasma $32-33$ split proinsulin concentration (Fig. 1) was also significantly higher in the patients with myotonic dystrophy $(7.8 \pm 2.5$ vs $2.9 \pm 0.4 \mathrm{pmol} / \mathrm{l}$, $p<0.05$ ). Plasma concentrations of $65-66$ split proinsulin were below the detection limit of the assay in the majority of subjects in each group (data not shown).

The overall response of immunoreactive insulin $(p<0.001)$ and C-peptide $(p<0.001)$ to the oral glucose challenge was significantly greater in the myotonic patients than in the healthy control subjects. Peak C-peptide concentrations at $60 \mathrm{~min}$ were $3.99 \pm 0.38$ vs $2.02 \pm$ $0.26 \mathrm{nmol} / 1(p<0.001)$ for the myotonic patients and the healthy control subjects, respectively.

\section{Discussion}

Fasting plasma immunoreactive insulin concentration, as determined using a conventional radioimmunoassay, was significantly elevated in the patients with myotonic dystrophy, being nearly three times higher than that for the healthy control subjects. By contrast, fasting concentrations of C-peptide and immunoradiometrically-determined insulin were only $\sim 50 \%$ higher in the myotonic dystrophy patients. Fasting plasma proinsulin and 32-33 split proinsulin concentrations were significantly elevated in the myotonic dystrophy patients suggesting that cross-reactivity of proinsulin-like molecules in the insulin radioimmunoassay led to an overestimation of the degree of fasting hyperinsulinaemia in these patients. Consistent with this view, significant correlations were observed between fasting concentrations of plasma C-peptide and immunoradiometrically-determined insulin.

Overall plasma immunoreactive insulin and C-peptide responses to the $75-\mathrm{g}$ oral glucose challenge were significantly greater in the myotonic patients. Since C-peptide does not undergo hepatic extraction, the concentration of this molecule in the systemic circulation is held to be a reliable marker of endogenous insulin secretion. The C-peptide response therefore provides corroborative evidence of increased beta-cell secretion in myotonic dystrophy [1].

The elevated plasma concentrations of proinsulin-like molecules suggest that beta-cell processing of proinsulin may be defective in myotonic dystrophy. Alternatively, differences in clearance rates of these molecules from the circulation could explain the elevated plasma concentrations of beta-cell products [9]. However, data from glucose clamp studies and our own incremental insulin infusion studies [2] suggest that the metabolic clearance rate of insulin is normal in myotonic dystrophy. Few data are available concerning clearance rates of proinsulin-like molecules in insulin-resistant states.
Elevated plasma concentrations of beta-cell conversion intermediates have been described in some other insulin-resistant disorders including impaired glucose tolerance and Type 2 diabetes $[5,6]$. In view of putative toxic effects of hyperglycaemia on beta-cell function [10] the elevated concentrations of proinsulin-like molecules in the present study is noteworthy since oral glucose tolerance, as defined by World Health Organization criteria, was normal in all the myotonic dystrophy patients [8].

In summary, in addition to increased insulin secretion, myotonic dystrophy is characterised by elevated fasting plasma concentrations of the beta-cell conversion intermediates proinsulin and $32-33$ split proinsulin. While the pathological significance of this phenomenon is unclear, the elevated concentrations of proinsulin-like molecules in myotonic dystrophy is consistent with recent observations in other insulin-resistant disorders in man.

Acknowledgements. We thank Ms S.Nutter, Mr. N.Coles, Mr. B. Cammies, Ms D. Wong and Ms A.Schneider for expert technical assistance. The financial support of the British Diabetic Association, the Medical Research Council, Eli Lilly, and the Bicentenary Advisory Committee of the General Hospital, Birmingham is gratefully acknowledged.

\section{References}

1. Krentz AJ, Coles NH, Williams AC, Nattrass M (1990) Abnormal regulation of intermediary metabolism after oral glucose ingestion in myotonic dystrophy. Metabolism 39: 938-942

2. Krentz AJ, Williams AC, Nattrass M (1991) Insulin resistance in multiple aspects of intermediary metabolism in myotonic dystrophy. Metabolism 40: 866-872

3. Flier JS (1983) Insulin receptors and insulin resistance. Annu Rev Med 34: 145-160

4. Poffenbarger PL, Pozefsky T, Soeldner JS (1976) The direct relationship of proinsulin-insulin hypersecretion to basal serum levels of cholesterol and triglyceride in myotonic dystrophy. J Lab Clin Med 87: 384-396

5. Williams DRR, Byrne C, Clark PMS et al. (1991) Raised proinsulin concentration as early indication of $\mathrm{B}$ cell dysfunction. $\mathrm{Br}$ Med J 303: 95-96

6. Temple RC, Carrington CA, Luzio SD et al. (1989) Insulin deficiency in non-insulin-dependent diabetes. Lancet I: 293-295

7. Sobey WJ, Beer SF, Carrington CA et al. (1989) Sensitive and specific two-site immunoradiometric assays for human insulin, proinsulin, $65-66$ split and 32-33 split proinsulins. Biochem J 260: 535-541

8. Diabetes Mellitus. Report of a WHO Study Group (1985) World Health Organization Technical Report Series no. 727, Geneva

9. Peavy DF, Brunner MR, Duckworth WC, Hooker CS, Frank BH (1985) Receptor binding and biological potency of several split forms (conversion intermediates) of human proinsulin. Studies in cultured IM-9 lymphocytes and in vivo and in vitro in rats. $J$ Biol Chem 260: 13989-13994

10. Unger RH, Grundy S (1985) Hyperglycaemia as an inducer as well as a consequence of impaired islet function and insulin resistance: implications for the management of diabetes. Diabetologia 28: 119-121

Received: 10 June 1992

and in revised form: 25 August 1992

Dr. M.Nattrass

The General Hospital

Steelhouse Lane

Birmingham $\mathrm{B} 46 \mathrm{NH}$

UK 